\title{
The Relationship between Capital Structure and Ownership Structure: Evidence from Listed Companies in Hotel and Manufacturing Sectors in Sri Lanka
}

\author{
K.M.K.N.S. Kulathunga ${ }^{1}$, L.A.S. Perera ${ }^{2}$, G.N Anagipura ${ }^{3}$ \\ Department of Finance, Faculty of Commerce and Management Studies, \\ University of Kelaniya, Sri Lanka, \\ ${ }^{1}$ nisansalas@kln.ac.lk, ${ }^{2}$ shanakapererauok@yahoo.com, ${ }^{3}$ gimhaninipunika@ gmail.com
}

\begin{abstract}
This study examines the relationship between capital structure and ownership structure for a sample of thirty-eight listed companies in the hotel and manufacturing sectors in the Colombo Stock Exchange (CSE) in Sri Lanka over the period of 2011-2015. All the secondary data were collected from audited annual reports of each company and data were analyzed using descriptive statistics and regression analysis. Mainly the ownership structure is measured using individual, managerial, institutional and share ownership concentration. Furthermore, the impact of Profit and Tangibility on capital structure is also examined in the study. The results revealed the managerial ownership and ownership concentration have significant influence on the capital structure. In the comparison of hotel sector and manufacturing sector listed companies in CSE we can identify that there is higher impact of ownership structure on capital structure in manufacturing sector compared to the hotel sector.
\end{abstract}

Keywords: Capital Structure, Ownership Structure, Managerial Ownership, Ownership Concentration.

\section{Introduction}

The relationship between ownership structure and capital structure is a famous topic in financial literature. Many noble scholars' like Leland and Pyle (1997), Jensen (1976) initial pay attention toward this topic and later scholars like Pindado and Torre (2011) and Brailsford T. O (2002) express their opinions on this area. The ownership structure and capital structure both are vital factors that decide the survival and prosperity of an entity. Therefore, the

${ }^{1} \mathrm{https}: / /$ orcid.org/0000-0003- 4722-0126 
relationship between ownership structure and capital structure is a notable topic to many scholars.

Capital structure choice is also grey issue in corporate finance in Sri Lanka because an optimal capital structure leads to maximize the market value of the firms with the performance of the organization. The appropriate selection of capital structure is a key element in firm financial strategy. The capital structure of a firm is determined by two decisions, they are type of securities issued and relative ratio of securities that determine the gearing of the firm. Many scholars have express different ideas on financing choices of an organization. According to Modigliani and Millar (1958) in real world with tax the ungeared firm will earn money \& pay tax. But similar geared firms will also earn money and pay less tax because interest is tax deductible, making the geared firm more valuable than ungeared firm. The selection of capital structure is a top management decision based on the approval of the shareholders.

As per the CSE in Sri Lanka listing rules, a public listed company must satisfy a specified public float in its issued share capital at the time of its initial listing and thereafter. In order to be quoted on the CSE, a company must have a minimum public holding of $10 \%$ of the total number of shares for which the listing is sought which shall be in the hands of a minimum number of 100 public shareholders holding not less than 100 shares each. Therefore, although individual shareholders in low number have less impact to company decisions, they have the ability to influence the company procedures.

The ownership structure is defined by the distribution of equity with regard to votes and capital, but also by the identity of the equity owners. As in many emerging markets in Asia, the ownership of many of the listed companies in Sri Lankan are highly concentrated with the presence of controlling shareholders in most enterprises (Kulathunga \& Azeez, 2015). This indicates corporate control of many Sri Lankan entities often lies in hand of few individuals apart from that insider ownership or corporate groups who hold majority of ownership. The concentration shareholders may have a high influencing power towards the company decisions that minority shareholders. As capital structure choice is a critical decision to make, it is important to identify the impact of ownership structure on capital structure.

This study aims at investigating the relationship between capital structure and ownership structure in listed hotels and manufacturing sector companies in Sri Lanka. Followings are the objectives of the study. 
- To identify the relationship between capital structure and ownership structure in listed companies in hotel and manufacturing sector.

- To determine the impact of ownership structure on capital structure.

- To compare the relationship of ownership structure and capital structure between the listed companies in hotel sector and manufacturing sector.

The study contributes to the literature not only in terms of extending existing empirical evidence on capital structure and ownership structure but also fills in the gap in the literature on focusing the listed companies in hotels and the manufacturing sectors in Sri Lanka.

Sectorial selection of hotel and manufacturing was mainly due to the rapid of growth in particular industries and their significance in future development of Sri Lanka. Further ownership structure of Sri Lankan hotel and manufacturing sector have its own embedded features that creates importance to seek for its exceptional relationship of ownership structure and capital structure.

\section{Literature Review}

The literature on the determinants of capital structure is extensive, and with considerable variations in findings. Since the publication of the article by Modigliani and Miller (1958) there have been numerous theories and studies that have evolved around the Modigliani-Miller theory, such as trade-off theory, pecking order theory, agency theory, etc. Information asymmetry is also widely used in the field of finance. No clear conclusion, however, has been established regarding the various theories referred to above. To put it another way, no single theory alone is adequate to explain the factors that affect a firm's capital structure. The capital structure choice of firms is generally the result of the mixture of a wide range of different factors.

The choice of the debt in capital structure is important for all firms. Since the work of Modigliani and Miller (1958) many studies have looked at the question of optimal debt level of a firm and why they choose that particular level. Large firms take on debt financing to gain tax benefits and the cheaper costs of debt compared to equity. However, Myers and Majluf (1984) explains that while firms can take advantage of debt for tax deductibility, they need to be careful not to increase their risk of bankruptcy not too much to avoid the increase the risk that the firm will go bankruptcy. 
However, it is also important to note that lower level of debt reduces bankruptcy risk and ensures that a firm remains sustainable even in hard times. Therefore, self-interested controlling shareholders have incentives to reduce corporate debt to a level which is less than optimal. Consequently, it can expect to observe a negative relationship between ownership concentration and capital structure.

According to the Samarakoon (1999), Senaratne and Gunaratne (2007) and by Kulathunga and Azeez (2015) the ownership structure of Sri Lankan listed firms is very much steady and characterized by certain features, such as highly concentrated ownership with a presence of controlling shareholder, holding controlling ownership usually by another corporate entity, holding ultimate ownership by family owners. Thus most of the Sri Lankan firms have stable ownership structure and therefore ownership is more likely to be exogenous to performance.

Furthermore, direct managerial ownership in Sri Lankan companies is relatively small, because ownership is usually dominated by another corporate entity. These entities usually have family ownership as the ultimate owners, and therefore, direct managerial ownership does not play an influential role in Sri Lankan context. However, individual owners have more powers in participating in the operational activities of a firm, especially in the Sri Lankan market, where controlling shareholders' influence in management is considerably high. The increase of managerial ownership force managers to take the responsibility of wealth consequence and thus coordinates the interests of management and shareholders. This reduces managerial incentives to consume perquisites and expropriate shareholders wealth (Jensen \& Meckling, 1976). The concentration of ownership in the hands of a few gives rise to agency conflicts between insiders (managers and controlling shareholders) and outsiders (minority shareholders). Mitton, (2002) and Johnson (1997-1998) argue that ownership concentration results in conflict of interest between controlling shareholders and minority shareholders, thereby increasing information asymmetries.

Institutional owners also play a key role in monitoring the firms in which they hold equity. Owners of the firm have different rights; such rights include the election of the board of directors, who will act as an agent to monitor the performance of the firms' managers. Institutional activism arises when the owners are disappointed with the performance of the board of directors (Gillan \& Starks, 2000).

Nobel scholars have done various studies on the relationship between the ownership structure and capital structure. By studying prior literature relate to the topic one can identified that 
there is a relationship between ownership structure and capital structure. However different scholars have present different views on the relationship between these two factors. Wellalage and Locke (2013) as use a panel of New Zealand unlisted firms from 1998 to 2009 to examine the relationship between ownership structure and firm leverage ratios. Although, the choice of the debt in capital structure is important for all firms, the scale effects may influence the degree of influence of particular financial theories upon capital structure. It is important to note that in order to control the endogeneity effect of insider ownership, this study uses the dynamic panel generalized method of moment estimation and uses the Granger causality test to check the causality effect of leverage and insider ownership.

Grier and Zychowicz (1994), reported a significant relationship between insider ownership and leverage and there is an inverse U-shape relationship of insider ownership and leverage, indicating higher insider ownership increases management entrenchment and lower insider ownership increases misalignment of the interests of management and owners. Apart from that the study also imply that managerial ownership negatively affects firms' total debt levels. Supporting to that conclusion Farooq (2015) present that firms with high ownership concentration tend to have low debt ratios. Furthermore, reluctance on the part of controlling shareholders to accumulate excess leverage to minimize non-diversifiable risk can also result in a negative relationship between ownership concentration and capital structure. Apart from that they also show that for a given level of ownership concentration, the proportion of debt in capital structure goes up as information asymmetries decrease. Finally, the results show that for a given ownership concentration, it is the growth firms with low information asymmetries that have a higher proportion of debt in their capital structure.

Similar conclusion has presented by Al-Fayoumi and Abuzayed (2009) from a study that examines the relationship between ownership structure and capital structure decisions of listed industrial firms in Jordan during the period 2001 to 2005. The components of ownership structure used for this study include managerial insiders, institutions and individual blockholders. Based on panel data methodology, the empirical results show negative statistically significant relationship between the managerial insiders and capital structure, suggesting that, managers employ lower debt in order reduce the performance pressures associated with high debt capital. The results of this study also show inconclusive significant association between capital structure and individual block-holders. They also find no evidence of the active 
monitoring role of institutional shareholders, indicating that those shareholders do not rely on capital structure decisions to monitor managerial behavior of the sampled firms.

Apart from that, the study also shows that the dynamic adjustment of capital structure of firms is examined in an agency theory context. Also it has studied how the capital structure is adjusted in response to shifts in agency cost tradeoffs. The results support the dynamic nature of adjustment of the Jordanian industrial firms' capital structure in response to shifts in the ownership structure through time. The results for the other explanatory variables, including profitability, size and growth indicate that each of these variables has a significant impact on the capital structure. Moreover, the signs of these variables are consistent with predictions. However, the other variables, including tangibility, risk and non-debt tax shield are insignificant.

Zhang (2013), examines the impact of ownership structure on capital structure of non-financial Chinese listed firms from 2007 to 2012. Pooled OLS regression has been used to investigate the influence of ownership related variables on firm's capital structure decision. The independent variables include ownership concentration, managerial ownership, state ownership and legal person ownership, controlling for the influence of common firm-related variables and industry effects. Final conclusion shows that there is a significant reversed Ushape nonlinear relation between ownership concentration and capital structure suggests that there might be an optimal level of ownership concentration. There is no evidence that managerial ownership affects firm's capital structure. The positive relation between state ownership and capital structure confirms the role of state in firms' corporate financing decisions, firms with state ownership prefer issue more debt to resolve severe agency problem between shareholders and managers. Besides, firms with state ownership access to bank loans easier than firms without state ownership, as well as access to long-term loans. There is a weak positive relation between legal person ownership and capital structure.

Contradictory conclusion to above views has been presented by Ganguli (2013) by investigating how ownership structure impacts the capital structure of the listed mid-cap companies in India and whether the capital structure as exogenous variable has a role in determining ownership structure as well. The empirical result on Indian firms suggests that the ownership structure does impact capital structure but not the vice versa. Also it finds that the leverage is positively related to concentrated shareholding but has a negative relation with diffuseness of shareholding after controlling for profitability, risk, tangibility, growth and size. 
Brailsford, Oliver and Pua (2002) have extended the literature by examining a further link between ownership structure and capital structure. Using an agency framework, it is argued that the distribution of equity ownership among corporate managers and external block holders may have a significant relation with leverage. The empirical results provide support for evidence that the distribution of equity ownership among external block holders has a statistically significant relation with leverage. The findings suggest that the level of external block ownership is positively related to leverage. This provides support for the active monitoring hypothesis which proposes that external block holders have greater incentives and an ability to monitor management, thereby reducing managerial opportunism which may otherwise reduce leverage to a sub-optimal level in order to reduce management's nondiversifiable employment risk.

Further it finds that the association between external block ownership and leverage varies across the level of managerial share ownership. Specifically, at low levels of managerial share ownership, the monitoring effect of external block ownership results in a positive relation between external block ownership and leverage. However, at high levels of managerial share ownership, managerial entrenchment competes with monitoring activities such that the significance of external block ownership is substantially removed.

Apart from above views researchers also have pay their attention toward ownership structure and firm performance \& capital structure. Shyu (2013) From study conduct to find out how agency problems and internal capital markets in group-affiliated firms are mutually influenced by the ownership structure, capital structure, and performance. Based on a sample of Taiwanese firms, the empirical findings indicate a U-shaped relationship between the insider ownership and the performance of group-affiliated firms. The distinct ownership structure of business clearly affects the agency problems. However, business groups can reduce such problems that occur in group affiliation by increasing insider ownership (after a certain tunneling point), debt financing, and dividend payout. Apart from those the researcher also said that Performance does not have an effect on insider ownership, which demonstrates that the ownership structure of group affiliates in Taiwan is not related to their performance. The finding that the capital structure decisions of group-affiliated firms are independent of firm performance and inside ownership, supports the view that the capital structure decisions of group-affiliated firms are determined by the overall characteristics of the business group, rather than those of the individual firm. 
Similar conclusion has presented by Godfred, Bokpin and Arko (2009) by examined the effect of ownership structure and corporate governance on capital structure decisions of firms on the Ghana Stock Exchange. To analyze the impact of ownership structure and corporate governance on firms' financing decisions, unbalanced panel data covering a period from 2002 to 2007 is employed. The empirical evidence shows that managerial share ownership significantly positively influences the choice of long-term debt over equity whilst foreign share ownership is insignificant in predicting corporate financing decisions. Board size is also significantly positively related to leverage implying that directors in general will substitute equity for long-term debt in their capital structure choices.

Whilst the researchers report insignificant relationships with the other measures of capital structure also. Asset tangibility which could serve as a collateral security is a significant predictive variable in the choice of especially short-term debt over equity. Volatility in earnings (risk) is also a significant determinant of capital structure decisions among firms on the GSE. In addition, profitable firms will significantly curtail external financing and resort to internally generated funds such as retained earnings. It also reported that, firms' capital structure decisions are taken alongside firms' dividend policy as we observe a significant relationship between dividend payment and capital structure decisions.

Recently, some studies have found a non-linear relationship between the levels of insider ownership and leverage. The one possible explanation for that is, according to "convergence of interest" hypothesis, insider ownership is positively related to a firm's debt level. This may be because a high level of insider ownership increases monitoring and reduces free-rider problems. Hence, high insider ownership increases debt ratios, because when monitoring by shareholders, managers cannot maintain low levels of debt to their own interests Pindado and Torre (2011).

Summarizing the literature of relationship between ownership structure and capital structure, many empirical evidence reflects there is asignifinant negative relationship between ownership structure and capital structure. Modigliani and Miller (1958) and Myers and Majluf (1984) discussed of optimum capital structure align with firm value and risk of bankrupcy of the firm structure across debt capital. Including Al-Fayoumi and Abuzayed (2009) and many other reserachers analyze the agency problem which airse due to ownership structure of the particular firm. further Samarakoon (1999), Senaratne and Gunaratne (2007) and by Kulathunga and Azeez (2015) have evaluated Sri Lankan aspect of ownership structure and its impact on 
performance, providing the evidence of concentration ownership structure in most of the listed companies in Sri Lanka. Hence the research foucs to fill the literature gap of conducting an emperical research on finding the relationship on ownership structure and capital structure comparing two main booming sectors in Sri Lanka.

\section{Methodology}

\section{Sample Selection and Data Collection}

The present include thirty eight listed companies in CSE based on market capitalization as of 31 December 2015. The study period covers the 2011 to 2015 period. The main justification for selecting firms with higher market capitalization companies is that, there is a greater tendency that these firms alter their finance and investment decisions and these are the two sectors that listed highest number of companies in CSE. Twenty companies represent each sector and few companies were excluded due to unavailability of data and due to the companies have not been listed on CSE continuously from 2011 to 2015. Due to the outliers in data for two companies, they have been removed from the selected sample. As a result, thirty-eight companies were included this study.

\section{Data Analysis}

Regression analysis was carried out using fixed effect and generalized least squares model. The preliminary analyses of sample data show that the data are free from autocorrelation, multicollinearity and heteroskedasticity problems.

The independent variables for the present study include individual ownership structure, managerial ownership structure, institutional ownership structure, consecration ownership structure, profitability and tangibility while debt to equity ratio is the dependent variable. Table 01 shows the measurement for each of the variables. 
Table 01 - Variables and Measurement

\begin{tabular}{|l|l|l|}
\hline Variables & Represent by & Measurement \\
\hline Debt to Equity Ratio & DER & DER = Debt Capital / Equity Capital \\
\hline $\begin{array}{l}\text { Individual Ownership } \\
\text { Structure }\end{array}$ & IND & No of Shares hold by individuals. \\
\hline $\begin{array}{l}\text { Managerial Ownership } \\
\text { Structure }\end{array}$ & MAN & No of Shares hold by managers, insiders. \\
\hline $\begin{array}{l}\text { Institutional Ownership } \\
\text { Structure }\end{array}$ & INS & No of Shares hold by institutions. \\
\hline $\begin{array}{l}\text { Concentration } \\
\text { Ownership Structure }\end{array}$ & OWN & Percentage of share hold by major shareholders. \\
\hline Return on Equity & ROE & ROE = (Net Income / Shareholder's Equity) *100 \\
\hline Tangibility & TAN & TAN = Fixed Assets / Total Assets \\
\hline
\end{tabular}

The model of the study is as follows;

$\mathrm{DER}_{i t}=\beta 0+\beta_{1} \mathrm{IND}_{\mathrm{it}}+\beta_{2} \mathrm{MAN}_{\mathrm{it}}+\beta_{3} \mathrm{INS}_{\mathrm{it}}+\beta_{4} \mathrm{OWN}_{\mathrm{it}}+\beta_{5} \mathrm{ROE}_{\mathrm{it}}+\beta_{6} \mathrm{TAN}_{\mathrm{it}}+\mathrm{U}_{\mathrm{it}}$

Where, $\beta 0$, is constant, $\beta_{1}, \beta_{2}, \beta_{3}, \beta_{4}, \beta_{5}, \beta_{6}$, are coefficients of variables.

\section{Findings and Discussion}

\section{Descriptive Statistics}

Table 02 depicts the descriptive data for each variable used in this present study. As show in table 02 there are 190 observation and valid $\mathrm{N}$ row shows number of observations after removing the outliers. According to the range column debt to equity ratio (DER) have highest range value as 1.38 where the maximum value is 1.38 and the minimum value is 0 . And Individual shareholder ownership (IND) has lowest range of 0.34 where the highest value is 0.357 and minimum value is 0.01 . Apart from those Managerial ownership (MAN) has range of 0.35 as the maximum value is equal to 0.35 and minimum value is 0 . Also 0.81 can be identified as range in Concentration Ownership (OWN) as the maximum value represented as 0.82 and minimum value represented as 0.01 . When consider the variable return on equity (ROE) the range is 0.46 , as the maximum value is 0.46 and the minimum value is -0.63 . The range of the variable tangibility (TAN) calculated by dividing fixed assets by total asset is 0.999 , where the maximum value is 0.999 and the minimum value is 0 . 
DOI: http://doi.org/10.4038/kjm.v6i2.7544

Table 02 - Summary of Descriptive Statistics

\begin{tabular}{|c|c|c|c|c|c|c|}
\hline & N & Range & Minimum & Maximum & Mean & $\begin{array}{c}\text { Std. } \\
\text { Deviation }\end{array}$ \\
\hline DER & 190 & 1.38 & 0 & 1.38 & 0.310 & 0.344 \\
\hline IND & 190 & 0.347 & 0.01 & 0.357 & 0.152 & 0.085 \\
\hline MAN & 190 & 0.35 & 0 & 0.35 & 0.016 & 0.060 \\
\hline OWN & 190 & 0.81 & 0.01 & 0.82 & 0.359 & 0.184 \\
\hline ROE & 190 & 0.46 & -0.63 & 0.46 & 0.149 & 0.150 \\
\hline TAN & 190 & 0.999 & 0 & 0.999 & 0.489 & 0.301 \\
\hline Valid N & 190 & & & & & \\
(list wise) & & & & & & \\
\hline
\end{tabular}

Source: Survey Data 2011-2015

Mean value simply referred to the average of numbers which is widely used measure of central tendency. According to the above table average debt to equity ratio of companies in hotel and manufacturing sectors in Colombo stock exchange is $31 \%$. The mean values of the table represent that average individual share ownership in hotel and manufacturing sectors in Colombo stock exchange is $15.2 \%$, average Managerial ownership is $1.6 \%$. The average return on equity in hotel and manufacturing sectors in Colombo stock exchange during the period 2011-2015 was $14.9 \%$ which mean the average return per Rs. 1 equity is 0.149 . And the average fixed asset to total asset ratio (Tangibility) during 5-year period is $48.9 \%$. Standard deviation measures the spread of a set of observations. The larger the standard deviation is, the more spread out the observations are. According to the above table debt to equity has higher spread while managerial ownership has lowest spread.

\section{Regression Results}

The results of the regression anaylsis of generalized least squres model are shown in the table 03. Results revealed that the overall model is significant with the R-Squared value of 44 percent. The 44 percent variation in the capital structure of listed hotels \& manufacturing sector companies in Sri Lanka is explained by the ownership structure and the other control variables. The individual ownership structure has negative relationship with capital structure while managerial and concentration ownership structure have significant positive impact with capital structure. ROE and TAN have insignificant negative relationship with capital structure. 
DOI: http://doi.org/10.4038/kjm.v6i2.7544

Table 03 - Output of GLS model

\begin{tabular}{|c|c|c|c|}
\hline Variable & Coefficient & t-Statistics & Prob \\
\hline C & 0.181689 & 3.002512 & 0.0030 \\
\hline IND & -0.154638 & -1.021259 & 0.3085 \\
\hline MAN & 2.623264 & 23.67333 & 0.0000 \\
\hline OWN & 0.377914 & 3.957622 & 0.0001 \\
\hline ROE & -0.159905 & -1.197119 & 0.2328 \\
\hline TAN & -0.90900 & -1.790719 & 0.0750 \\
\hline R - Squared & Weighted Statistics & & \\
\hline Adjusted R - Squared & & & 0.446475 \\
\hline F - Statistics & & & 0.431433 \\
\hline Prob (F- statistics) & & & 29.68297 \\
\hline
\end{tabular}

Source: Survey Data 2011-2015

When consider the independent variable, individual ownership it can note that the variable is negatively relate to the dependent variable. Which mean when the individual shareholder percentage increases, debt to equity ratio decreases. In other words, when individual ownership percentage increase the company debt component relate to the equity ownership will decrease. The $\mathrm{t}$ - statistic value of the variable is -1.02 which is less than 2 , therefore the variable is insignificant. It can conclude that the individual ownership has not significant influence over the capital structure in hotel and manufacturing sectors in Sri Lanka. A similar conclusion has presented by Short, Keasey and Duxbury (2002) the debt ratio is negatively related to ownership by large external shareholders. And few scholars like Brailsford, Oliver and Pua (2002) suggest a contradictory conclusion that the distribution of equity ownership among external block holders has a statistically significant relation with leverage and suggest that the level of external block ownership is positively related to leverage.

It can identify that managerial ownership (MAN) and Ownership concentration (OWN) are positively correlate to the capital structure and the relevant that $\mathrm{t}$ - statistics are 23.67333 and 3.957622 respectively which are greater than 2 . That mean those are significant variables and the relevant probability values are 0.0000 and 0.0001 respectively. Therefore, it can conclude that the both managerial ownership and ownership concentration are significant at $1 \%$ level in 
DOI: http://doi.org/10.4038/kjm.v6i2.7544

GLS test. In other words, managerial ownership (MAN) and Ownership concentration (OWN) have significant influence over the capital structure in companies in hotel and manufacturing sectors.

In reviewing the prior literature we can figure out that few noble scholars have present a similar opinions. According to the by Short, Keasey and Duxbury (2002), Godfred, Bokpin and Arko (2009) and Pindado and Torre (2011) the debt ratio is positively related to management ownership. However also it can identify the literature which present contradictory conclusions. The studies conducted by Wellalage and Locke (2013), Farooq (2015) and Al- Fayoumi and Abuzayed (2009) suggest a negative statistical significant relationship between the managerial insiders and capital structure, suggesting that, managers employ lower debt in order reduce the performance pressures associated with high debt capital.

Ganguli (2013) argued leverage is positively related to concentrated shareholding which is similar view to this study related to ownership concentration. Farooq (2015) identified that negative relationship between ownership concentrations which is a contradictory result compared to this study. It can also identify that the control variables Return on equity and tangibility are negatively relate to the capital structure and they are insignificant. Because relevant $\mathrm{t}$ - statistic values of return on equity and tangibility are -1.19 and -1.79 respectively which are less than two. And it can note that the independent variables describe $44.64 \%$ of dependent variables because the $\mathrm{R}^{2}$ value is 0.4464 . The probability of $\mathrm{F}$ - statistics is 0.0000 which mean the overall model is significant at $1 \%$ level. In other way the independent variables which represent ownership structure and the control variables have joint influence over the dependent variable, capital structure.

\section{Comparison between hotel and manufacturing sectors}

Apart from identifying the relationship between the capital structure and ownership structure in hotel and manufacturing sectors in Colombo Stock Exchange, the study also aims to examine the capital structure and ownership structure of both the sectors separately as well.

For that analysis was done for two sectors separately using GLS test. The output regarding the analysis of relationship between capital structure and ownership in hotel sector can be identified as follows. 
Table 04 - GLS test for Hotel Sector

\begin{tabular}{|c|c|c|c|}
\hline \multicolumn{1}{|c|}{ Variable } & Coefficient & $\mathrm{t}-$ statistics & Prob. \\
\hline C & 0.567228 & 6.396549 & 0.0000 \\
\hline IND & -0.40166 & -1.396168 & 0.1661 \\
\hline MAN & -4.293572 & -8.136168 & 0.0000 \\
\hline OWN & -0.05096 & -0.347670 & 0.7289 \\
\hline TAE & -0.057876 & -0.674609 & 0.5017 \\
\hline RAN & -0.410768 & -4.976147 & 0.0000 \\
\hline R - Squared & Weighted statistics & \\
\hline Adjusted R - Squared & & & 0.56667 \\
\hline F - statistics & & & 0.54233 \\
\hline Prob (F - Statistics) & & & 23.2773 \\
\hline
\end{tabular}

Source: Survey Data 2011-2015

According to the table 04 Individual ownership is negatively correlate to the capital structure and the $\mathrm{t}$ - statistic is -1.396168 which is greater than two. Hence the individual ownership does not have significant influence over the capital structure. When consider the managerial ownership it can identify a negative relationship with the capital structure and it has significant influence over the capital structure because the $\mathrm{t}$ - statistics value is -8.13 , which greater than 2 and the relevant probability is 0.0000 which mean it is significant at $1 \%$ level. Ownership concentration which is measured by herfindal index also has insignificant negative relationship with capital structure as the $\mathrm{t}-$ statistics is -0.34 which is less than two. The control variable ROE also has negative insignificant relationship with capital structure as the $\mathrm{t}$ - statistic value is -0.67 which is lower than two. That mean the ROE has not significant influence over the capital structure. When consider the asset tangibility, it has negative significant influence over the capital structure. According to the output the $\mathrm{t}$ - statistic value is -4.97 which is greater than two and the relevant probability value is 0.00 , hence it can identify that tangibility is significant at $1 \%$ level.

According to the table 03 the $\mathrm{R}^{2}$ value is 0.5667 which indicate that $56.67 \%$ of dependent variable is explained via the independent variables, independent ownership, managerial ownership, ownership concentration and the control variables return on equity and tangibility. The probability of F Statistic is 0.0000 which mean the overall model is significant. Therefore, 
it can conclude that the ownership structure variables independent ownership, managerial ownership, ownership concentration and the control variables return on equity and tangibility have joint influence over the capital structure in hotel sector in Colombo stock exchange.

The output regarding the analysis of relationship between capital structure and ownership in hotel sector can be identified as follows.

Table 05 - GLS test for Manufacturing Sector

\begin{tabular}{|c|c|c|c|}
\hline \multicolumn{1}{|c|}{ Variable } & Coefficient & $\mathrm{t}$ - statistics & Prob. \\
\hline C & 0.137263 & 1.911099 & 0.0592 \\
\hline IND & -0.333457 & -1.897421 & 0.0610 \\
\hline MAN & 2.561772 & 14.12047 & 0.0000 \\
\hline OWN & 0.628858 & 5.051770 & 0.0000 \\
\hline ROE & -0.568672 & -2.826926 & 0.0058 \\
\hline TAN & 0.176428 & 1.502288 & 0.1366 \\
\hline \multicolumn{1}{|l|}{ Weighted statistics } & & \\
\hline R - Squared & & & 0.847310 \\
\hline Adjusted R - Squared & & & 0.838732 \\
\hline F - statistics & & & 0.000000 \\
\hline Prob (F - Statistics) & & & \\
\hline
\end{tabular}

Source: Survey Data 2011-2015

According to the above output it can figure out that managerial ownership has positive significant influence over the capital structure because the $\mathrm{t}$ - statistic value is 14.12 which is greater than two. And the relative probability value is 0.0000 which indicate that managerial ownership is significant at $1 \%$ level. Ownership concentration also have positive significant influence over the capital structure because the $\mathrm{t}$ - statistic value is 5.05 which is greater than two and the probability value is 0.0000 , hence it is significant at $1 \%$ level. Return on equity also has significant influence over the capital structure. Because the $t-$ statistic value return on equity is -2.82 respectively which are higher than two. And it can note that the variable is significant at $1 \%$ level, as the probability value is 0.0058 . Only the independent share ownership has negative insignificant influence over the capital structure and tangibility has positive insignificant influence over the capital structure. The R squared value of GLS model was 0.847310 hence it can argue that in manufacturing sector the independent variables 
DOI: http://doi.org/10.4038/kjm.v6i2.7544

describe $84.73 \%$ of dependent variables. Finally, it can conclude that the overall model is significant at $1 \%$ level as the probability of $\mathrm{F}$ - Statistics is 0.0000 . It means that the independent variables have joint influence over the dependent variable.

\section{Conclusion}

The main consideration of this study is to identify the relationship between capital structure and ownership structure in hotel and manufacturing sectors in Sri Lanka. For that the researcher has selected 19 listed companies in hotel sector for period of five years and 19 listed companies in manufacturing sector for period of five years as the sample based on the market capitalization. By studying the prior research done by noble scholars' independent share ownership, institutional share ownership, managerial share ownership and ownership concentration which is measured by herfindal index were selected as independent variables and return on equity and tangibility were selected as control variables. In order to measure the capital structure debt to equity ratio was selected by researcher. However, during the data analysis one company from hotel sector and one company from manufacturing sector was removed due to the outliers, reducing the total sample in to 38 companies.

Based on the output it can identify that managerial ownership and ownership concentration has a positive significant relationship with capital structure. This may be because a high level of insider ownership increases monitoring and reduces free-rider problems. Hence, high insider ownership increases debt ratios, because when monitoring by shareholders, managers cannot maintain low levels of debt to their own interests Pindado and Torre (2011). The individual share ownership, return on equity and tangibility have negative insignificant relationship with capital structure.

In the comparison of the hotel sector and manufacturing sector, it can be identified that the individual share ownership has a negative insignificant relationship with capital structure in the both sectors. When consider the managerial share ownership, it has a negative significant relationship with capital structure in hotel sector and a positive significant relationship with capital structure in manufacturing sector. Ownership concentration has negative insignificant relationship with capital structure in hotel sector. A contradictory result can be identified in manufacturing sector as it can identify a positive significant relationship with capital structure.

In hotel sector it can observe that the return on equity has a negative insignificant relationship with capital structure and in manufacturing sector return on equity have negative significant 
DOI: http://doi.org/10.4038/kjm.v6i2.7544

relationship with capital structure. Tangibility has a negative significant impact with capital strucutre in the hotel sector. A contrary result can be identified in manufacturing sector, where a positive insignificant relationship can be identified. The ownership structure has considerably high influence over capital structure in manufacturing sector when compared to hotel sector.

Future research directions can be suggested to explore the relationship of ownership structure and capital structure of other sectors in the CSE. There are eighteen other sectors excluding hotel and manufacturing sectors, therefore future research can be expanded to such other sectors of CSE. Further the research can be expanded to all the companies in the CSE as well or either future researchers can take different combinations of sectors for the comparison of relationship of ownership structure and capital structure.

\section{References}

Al-Fayoumi, N., \& Abuzayed, B. (2009). Ownership structure and corporate financing. Applied Financial Economics, 19 (24), 1975-1986.

Brailsford, T., Oliver, B., \& Pua, S. (2002). On the relation between ownership structure and capital structure. Accounting and Finance, 42 (1), 1-26.

Farooq, O. (2015). Effect of ownership concentration on capital structure: Evidence from the MENA region. International Journal of Islamic and Middle Eastern Finance and management,8(1), 99-113.

Ganguli, S. (2013). Capital structure - does ownership structure matter? theory and indian evidence. Studies in Economics and Finance, 30 (1), 56-72. doi: 10.1111/j.14682443.2010.01115.x.

Gillan, S. L., \& Starks, L. T. (2000). Corporate governance proposals and shareholder activism: role of institutional investors. Journal of Financial Econmics, 57 (2), 275-305.

Godfred, A., Bokpin, A., \& Arko. (2009). Ownership structure, corporate governance and capital structure decisions of firms: empirical evidence from Ghana. Studies in Economics and Finance, 26 (4), 246-256.

Grier, P., \& Zychowicz, E. J. (1994). Institutional investors, corporate discipline and the role of debt. Journal of Economics and Business, 46, 1-11. 
DOI: http://doi.org/10.4038/kjm.v6i2.7544

Jensen, M. C., \& Meckling, W. H. ( 1976). Theory of the firm: managerial behavior, agency costs and ownership structure. Journal of Financial Economics, 3(4), 305-360.

Johnson, S. B. (1997-1998). Corporate governance in the Asian financial crisis. Journal of Financial Economics, 58 (1-2), 141-186.

Kulathunga, K. M. K. N. S., \& Azeez, A.A. (2015). The impact of ownership structure on dividend policy: Evidence from listed companies in Sri Lanka. Journal of Accountancy and Finance, 02 (01), 52-70.

Mitton, T. (2002). A cross-firm analysis of the impact of corporate governance on the East Asian financial crisis. Journal of Financial Economics, 64 (2), 215-241.

Modigliani, F., \& Miller, M. (1958). The cost of capital, corporation finance and the theory of investment. The American Economic Review, 48 (3), 261-297.

Myers, S., \& Majluf, N. (1984). Corporate financing and investment decisions when firms have information that investors do not have. Journal of Financial Economics, 13 (2), 187 221.

Pindad, J., \& Torre, C. (2011). Capital structure: New evidence from the ownership structure. International Review of Finance, 11 (2), 213-226.

Samarakoon, L. P. (1999).The ownership structure in Sri Lankan companies, Sri Lanakan Journal of Management, 4 , 143-157.

Senaratne, S., \& Gunaratne, P. (2007). Ownership Structure and Corporate Governance of Sri Lankan Listed Companies. Paper presneted in The 4th International Conference on Business Management. Faculty of Management Studies and Commerce, University of Sri Jayewardenepura Sri Lanka.

Short, H., Keasey, K., \& Duxbury, D. (2002). Capital Structure, management ownership and large external shareholders: A UK analysis. International Journal of the Economics of Business, 9 (3), 375-399. doi: 10.1080/1357151021000010382.

Shyu, J. (2013). Ownership structure, capital structure, and performance of group affiliation: Evidence from Taiwanese group-affiliated firms, Managerial Finance, 39 (4), 404 420. 
DOI: http://doi.org/10.4038/kjm.v6i2.7544

Wellalage, H. N., \& Locke, S. (2013). Capital structure and its determinants in New Zealand firms, Journal of Busniess Economics and Management, 14 (5), 852-866.

Zhang, L. (2013). The Impact of ownership structure on capital structure: Evidence from listed firms in China. University of Twente: School of Managment and Governence Financial Management. 